\title{
宿題報告
}

\section{4. びまん性沉細気管支炎とマクロライドの新作用}

\section{工藤 翔二}

Key words：びまん性沉紐気管支炎，エリスロマイシン療法，マクロライド新作用

\section{DPBの疾患概念の確立と国際的認知}

DPBの組織形態像は呼吸細気管支を中心とし た細気管支炎及び細気管支周囲炎からなる。焱 症の主体はりンパ球・形質細胞で，しばしばリ ンパ滤胞の形成を伴い，閉塞した呼吸細気管支 及びその末梢側の肺胞道や壁内には泡沫細胞の 集簇がみられ，進行すると閉塞部位から中枢側 の細気管支が二次的に拡張する。このような病 理組織所見を伴う疾患が、注目されはじめたの は 1960 年代の後半である. 1969 年, 本間, 山中 らによって,このような病理組織学的特徵を持っ た疾患が, 臨床病理学的に独立した疾患概念と して“びまん性沉細気管支炎”という名称と共 に提唱されだ，その後䄪 10 年にわたる “独立 疾患か否か”，“病変の主座”等に関する国内に おける議論を経て，ようやく概念・名称ともに 定着し,本間・山中らの提唱から 14 年を経た 1983 年, 初めて欧米誌 (Chest) にその疾患概念が紹 介された 2 。この 14 年という間隙は，本疾患が 欧米には稀であるという，後述する人種依存性 と無縁ではない，90 年代にはいるとFraser \& Pare $^{3)}$ のDiagnosis and Diseases of the Chest はしめ欧米の教科書にも記載され, 世界的に知 られるようになった。近年，DPBに関する欧文

くどうしょうじ：日本医科大学内科学第四
論文が増加しており，その大部分はわが国の著 者によっている。このことは，DPBはわが国か ら世界に発信する学問であることを如実に示し ている.

\section{2. 臨床診断基準の変遷}

$\mathrm{DPB} の$ 臨床診断基準は，厚生省特定疾患間質 性肺疾患調査研究班（班長：本間日臣）による 昭和 55 年（1980 年）の「びまん性汎細気管支炎 診断の手引(暫定案) 」4)をもとに，昭和 57 年 (1982 年)に策定されたものが最初である.昭和 61 年（1986 年）の第 83 回日本内科学会総会に おける本間日臣による宿題報告5)の中で, 若干の 追加項目と注を含む修正が提案され，慢性副鼻 腔炎の既往ないし合併, 寒冷凝集素価高值, HLABw54（現在のB-54）等が言及された。平成 7 年 (1996 年), 厚生省特定疾患びまん性肺疾患調査 研究班（班長：安藤正幸）によって，昭和 57 年の基準策定以来 13 年ぶりに改訂が行われた6). ここでは，“呼吸細気管支を病変の主座とする” という譟解を招きやすい表現を“呼吸細気管支 領域の慢性炎症を特徴とする”に改めるととも に，慢性副鼻腔炎の合併や肺聴診所見等の若干 の臨床項目が改訂され, HRCTによる小葉中心性 粒状院影が加えられた。さらに平成 10 年(1999 年), 厚生省研究班 (班長：工藤翔二) は臨床診 断項目の重み付けと重症度分類を付加した再度 


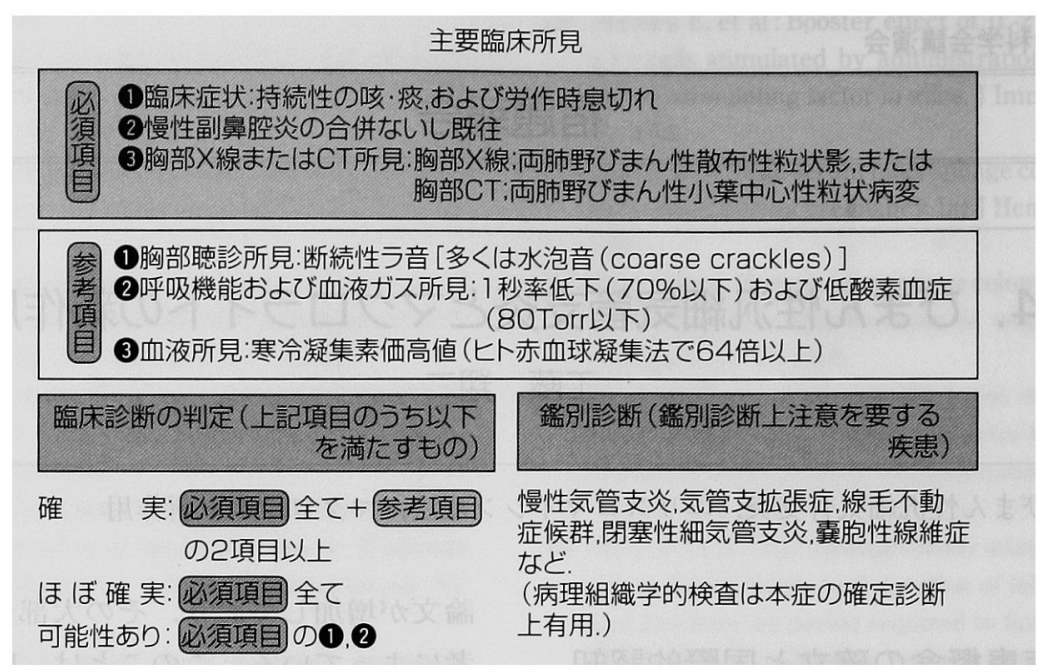

図 1. 主要臨床所見・臨床診断（中田紘一郎：厚生省特定疾患呼吸器系疾患調査研究班「びまん 性肺疾患分科会」平成 10 年度報告書, p. 109 より改変)

の臨床診断基準改訂を行い，現在用いられてい る7) (図 1).

\section{3. 副鼻腔気管支症候群の提唱と遺伝性要 因研究の始まり}

DPBの発症に遺伝性体質が関与していること は，いくつかの事実から示唆されてきた。 その 第 1 は, DPBのほとんどが慢性副鼻腔炎の合併 ないし既往を有することである.これには,三上8) による副鼻腔気管支症候群の提唱とその視点か らDPBを捉えようとする見解の果たした役割が 大きい.また，滝沢ら ${ }^{9}$ はDPBを“慢性気管支鞘 炎”として同様の考え方を示した。これらは欧 米のcystic fibrosisやimmotile cilia症候群にみら れる慢性副鼻腔炎と同様に, 上気道から下気道 に至るなんらかの気道防御機能障害の存在を想 定したものであった．第 2 は，DPBの家族発生 例の存在とわが国の副鼻腔気管支症候群におけ

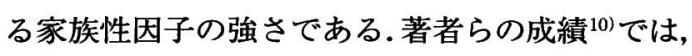
DPBを含む副鼻腔気管支症候群 50 例中 27 例 $(54 \%)$ が，二親等以内の家族に副鼻腔炎ないし
副鼻腔気管支症候群がみられた．第 3 は，DPB が人種特異性である可能性が強いと判断された ことである. 90 年代初頭まで欧米からはDPB の症例報告がみられず, わが国を除けば韓国 ${ }^{11)}$, 台湾 ${ }^{12)}$ に限られていた. 第 4 は, モンゴリアンだ けが保有するHLA抗原Bw54（現在のB-54）との 相関がきわめて高かったことである13).このこと について，著者らは珪肺症に係わるBw-54 保有 者に関する指摘 ${ }^{14)}$ に準じて, 当時, DPBを生体反 応のhyperresponderに扔ける上・下気道の持続 感染（副鼻腔気管支症候群）を基盤とする呼吸 細気管支領域の特異な炎症反応 (hyperresponse) と考えた.

\section{4. 人種特異性に関する国際交流調査}

1998 年までに, 東アジア地域以外からの本疾 患の症例報告は 18 症例ときわめて少なく, うち 9 症例が日本人, 韓国人及びアジア系移民である こと, また, 欧米の報告例の中には他疾患（組 織標本検討会, 97 年 2 月, 東京) や肺移植後症 例, 潰瘍性大腸炎合併例等の混在があることが 


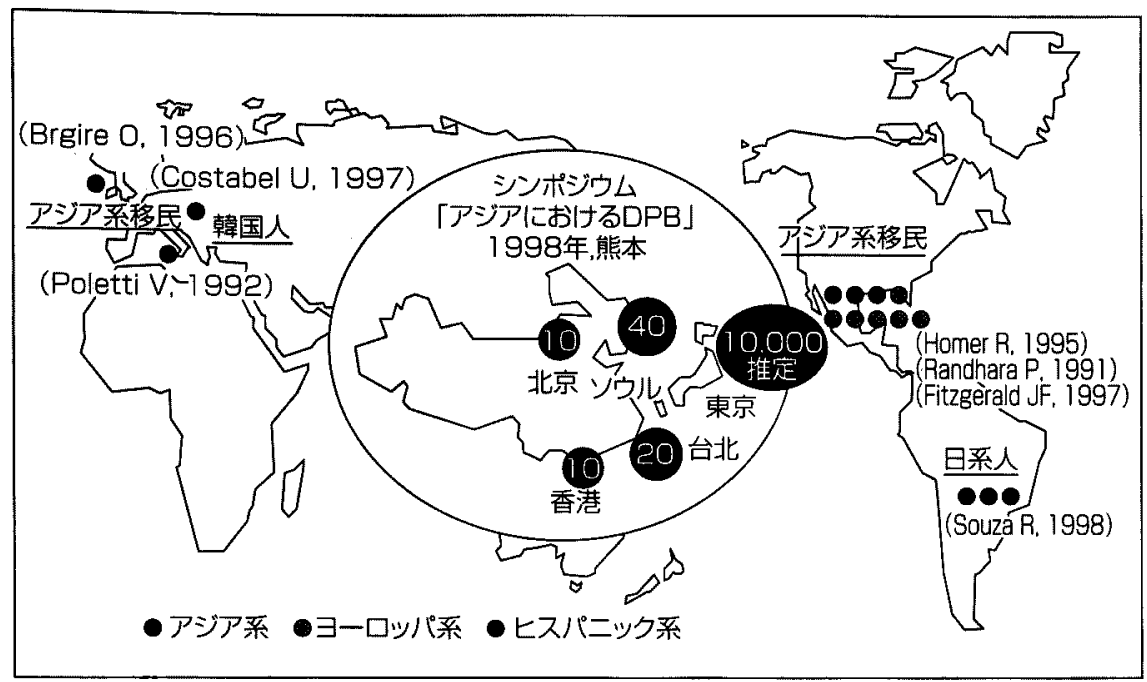

図 2. 世界のびまん性沉細気管支炎 (DPB) (工藤原図)

第 38 回日本呼吸器学会紷会 (会長：安藤正幸)における特別報告「アジアにおけるDPB」の場で, 東アジア各国よりDPB発症の現状が報告された。

明らかとなった。この頃は欧米では未だ，DPB を日本の風土病として症例報告に日本への旅行

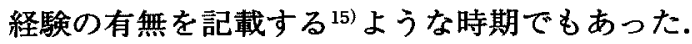

一方，日本以外の東アジア地域からは韓国， 台湾から報告例があるものの，中国大陸におけ る実態は全く明らかでなかった。そのため厚生 省 (当時) 特定疾患びまん性肺疾患調査研究班 (班長：安藤正幸) は，東アジア地域の実態を明 らかにするために, 1993 年から調查活動を開始 した. 中国事前調査 (北京, 95 年)，日中合同DPB 検討会（北京，96 年）における中国第 1 例の発 見 ${ }^{16)}$, 韓国事前調查（ソウル，97 年）を経て,

第 38 回日本呼吸器学会 (会長：安藤正幸)にお いて、シンポジウム“アジアにおけるDPB”が 開催された (98 年, 熊本) ${ }^{17)}$ ここのシンポジウム では, 北京 10 例, ソウル 40 例, 台北 20 例, 香 港 ${ }^{18)} 10$ 例など, これら諸都市におけるDPBの奏 態が報告された（図 2).また，cystic fibrosis は,このシンポジウムに参加した諸都市では, 欧米人以外ではほとんど経験されていないこと が明らかになったことも大きな収穫であった。
その後，韓国では独自の国内調查を実施し 132 例のDPBを収集,中国では約 40 例が報告されて おり,さらに,マレーシア ${ }^{19)}$, タイ ${ }^{20)}$, シンガポー ル21)などDPBはアジア全域で確認されている.

\section{HLA関連疾患感受性遺伝子の探求}

このような臨床疫学的事実をもとに，今日， DPBを多因子疾患とみなす立場から，主要な疾 患感受性遺伝子の所在追求が進められてきた。 従来, DPBはモンゴリアンのみが保有する HLAClass1 抗原B54 との相関が知られていたが,

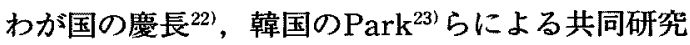
によって，日本人ではB54との相関を再確認する とともに，韓国人ではA11の頻度が高いこと， 両国人に共通ハプロタイプB54-Cw1-A11 が存在 することが明らかになった，そして，この両国 患者のHLAの差異の説明のために, DPBの主要 な疾患感受性遺伝子が第 6 染色体HLA遗伝子A 座とB座の間に存在し,進化の過程で日本人では A11 側, 韓国人ではB54 側に遺伝子組み替えが 


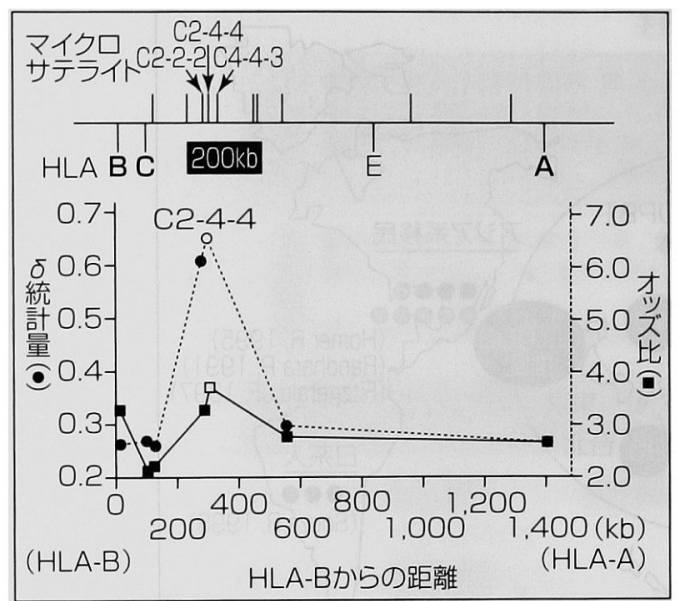

図 3. DPB主要感受性遺伝子座の推定 (慶長直人, 文献 24 上り引用改変)

疾患感受性ハプロタイプから推定された共有分節の 範囲（四）と，マーカーと疾患との関連性の強さ を表す指標であるオッズ比, 統計值が最高点を示す 位置を示す.また解析したマーカーと周辺の遺伝子 座を示す. 太字のB，C，Aは，それぞれHLA-B，C， $\mathrm{A}$ 遺伝子座. HLA-B A A座間はおよそ 1,400kb離れて いる.

生じたのではないかとする仮説が提起された. この仮説に基づいて精力的に開始された疾患感 受性遺伝子の探索によって, HLA遺伝子A, B 座間の未知領域 $200 \mathrm{kB}$ に相関の高い部分が認め

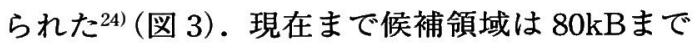
絞られており，すでにいくつかの新たな遺伝子 が発見されている. 近い将来, 主要疾患感受性 遺伝子が明確になることが期待されるが，その 保有ないし異常が気道防御系のいかなる障害要 因として作用するかが次なる課題となるだろう. 周知のように, DPBの組織学的な特徵は呼吸細 気管支領域のリンパ球と泡沫細胞の集積であり, リンパ球はmemoryT細胞とHLA-DRを発現した 活性化CD8（なかでもCytotoxicT細胞）を主体 とする ${ }^{25,26)}$. 疾患感受性遺伝子が, とりわけ気道 系の感染に対する難治化と呼吸細気管支領域の 過剩反応性をもたらす, 何らかの共通機序に結 びつくことが期待される.

\section{6. エリスロマイシン少量長期療法の発見 と確立}

EM療法以前のわが国の有病率は, 10 万対 11.1 とされており, 約 1 万人前後の患者が存在して いたと推定される ${ }^{27)}$. 当時はDPBの疾患概念確立 の時代であると同時に治療の最も困難な時代で あり, 厚生省研究班の報告（1982 年）では初診 時からの 5 年生存率で $42 \%$ とされていた ${ }^{28)}$. 気 道感染菌をみると, 初診時 $44 \%$ であったインフ ルエンザ菌は最終観察時には $16 \%$ に減少する ${ }^{29)}$ 一方, 緑膿菌が $22 \%$ から $60 \%$ に増加し, 緑膿 菌感染後の 5 年生存率はわずか $8 \%$ と劣悪なも のであった。この頃, DPBにおける進行性の呼 吸困難と予後の不良さが, 患者と医師をいかに

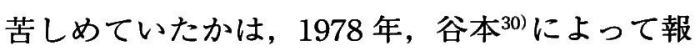
告されたDPB剖検例 15 例のうち，1例が自殺, 2 例が自殺未遂後の呼吸不全悪化によるもので あったという事実からも窺い知ることができる.

EM療法の発端症例 (54 歳男性) ${ }^{31)}$ は東大第 3 内科に入院し, 開胸肺生検 (虎の門病院)によっ てDPBの組織診断が得られ, 約 5 年間ステロイ ドや各種の抗生物質の治療にも拘わらず次第に 悪化, 受診を中断した. 2 年後の 1982 年, 再び 登場したときには, 自覚症状はほとんどなく, $\mathrm{PaO} 2$ は55Torrから 85Torrに改善していた(図 4). 本例はこの間, 松本市の開業医, 宮沢博医 師のもとに通院しており, その処方内容の一つ がEM 600mgであった.

本症例を契機として著者らはDPBに対するEM 少量長期療法の試みを開始し, 1984 年に初めて 報告した ${ }^{32}$ 。この報告を含め初期の個別施設にお ける成績33 36)の中に，すでに本療法の臨床的な 特徵が認められている. 第 1 は, 主治医判定で 有効率がきわめて高いこと．第 2 に, 治療前後 に喀痰中の感染細菌の種類がほとんど変化しな いこと.第 3 に, EMに感受性を持たない緑膿菌 感染例でも有効性がみられたことである，その 


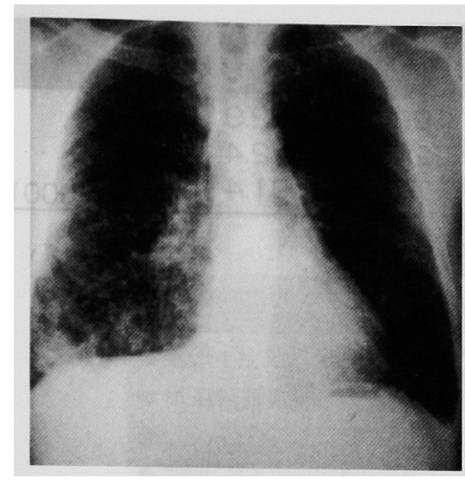

$1979 / 12 / 27$

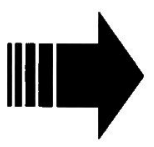

$1982 / 4 / 12$

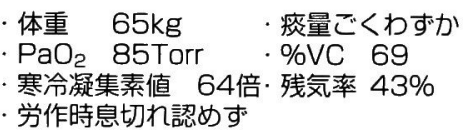

図 4. 発端例の眴部X線写真所見の変化（工藤翔二ほか：日胸疾会誌，25（6）,632, 1987）

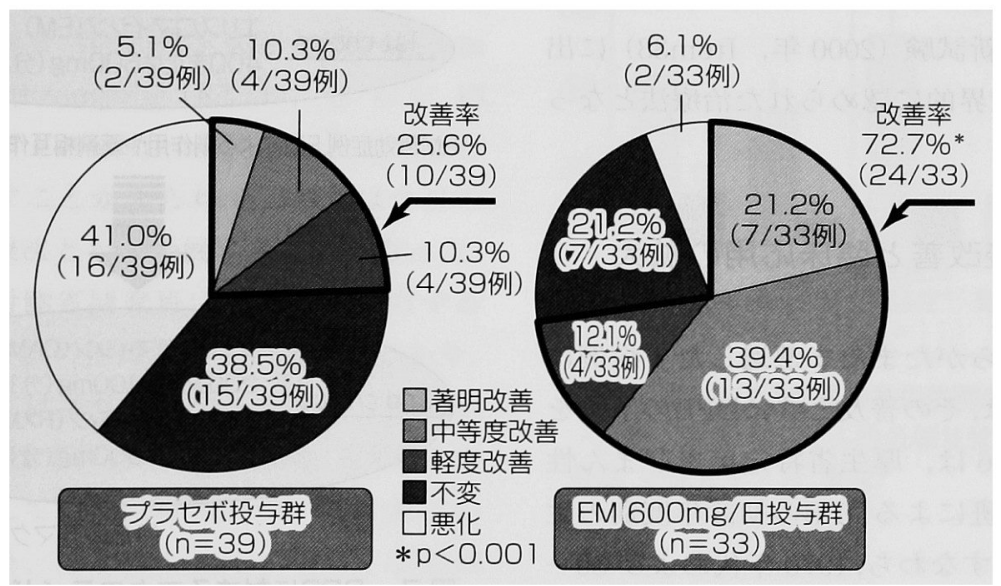

図 5. 総合判定成績

（労作時息切れ，胸部X線所見, $\mathrm{PaO}_{2}, 1$ 秒量, $\mathrm{CRP}$, 早朝咯痰量の 6 項目により判定）

（山本正彦：厚生省特定疾患「びまん性肺疾患」調查研究班 平成 2 年度報告書, p.18）

後, 関東地区 6 施設の合同調査 ${ }^{37)}, 1988$ 年の厚 生省「びまん性肺疾患」調查研究班によるニュー キノロンとの比較検討 ${ }^{38)}$ 等のレトロスペクティブ 多施設臨床研究が行われ, 1990 年には厚生省研

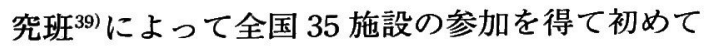
のプロスペクティブスタディとして, EM 600mg 投与群 (34 例), プラセボ群（39 例）との間の 二重盲検群間比較試験が実施された（図 5). 投
与期間は 3 カ月間と短いが, 総合改善度の客観 評価の方法として, 労作時呼吸困難（HughJones), 早朝 1 時間痰量, 胸部X線所見, $\mathrm{PaO} 2$, CRP, 寒冷凝集素価の 6 項目を点数化して評価 された. その結果, +2 点以上の中等度改善以上 はEM群で $57.6 \%$ ，プラセボ群で 15.4\%，また, 悪化はEM群 $6.1 \%$ に対してプラセボ群 $38.5 \%$ で あった.この二重盲検比較試験によって，わが 


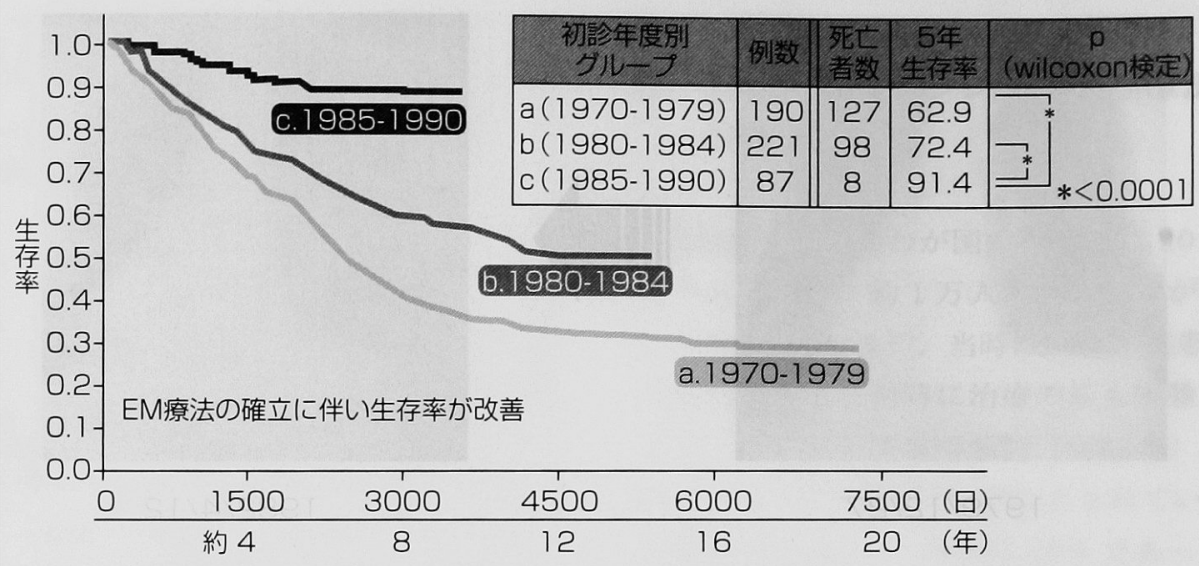

図 6. DPB患者の初診年度別生存率の推移（Kudoh S, et al : Am. J. Respir. Crit. Care Med., $157: 1829,1998)$

国におけるDPBに対するEM療法の臨床的有効性 が確立されたと言ってよい.今日, 本療法は米 国内科専門医更新試験（2000 年, Item33）に出 題されるなど,世界的に認められた治療法となっ ている.

\section{DPBの予後改善と臨床応用の拡大}

1982 年, 著者らがたまたま遭遇した 1 症例に 始まるEM療法は, その普及と共にDPBの予後を 一変させた。図 6 は, 厚生省特定疾患びまん性 肺疾患調查研究班によるDPBの初診年度別の生 存曲線 ${ }^{40)}$ である.すなわち, 1970 年代および 80 84 年に厚生省研究班に登録された患者の 5 年後 の生存率は, それぞれ $62.9 \%, 72.4 \%$ であったが, 85 年以降の登録者では $91.4 \%$ に改善している. これらの患者の年間死亡率も 1985 年までは年間 10\%であったが，EM療法が導入された 1986 年以後に急速に低下し, 1988 年には $2 \%$ 前後に なっており ${ }^{41)}$, 発症早期に治療を開始すれば, 今 日ではDPBは治し得る疾患になったと言って過 言ではない.

このようにして確立したEM療法は, やがて他 の気道系慢性炎症性疾患に応用されることとな る. 前述の関東地区におけるDPB症例の検討過

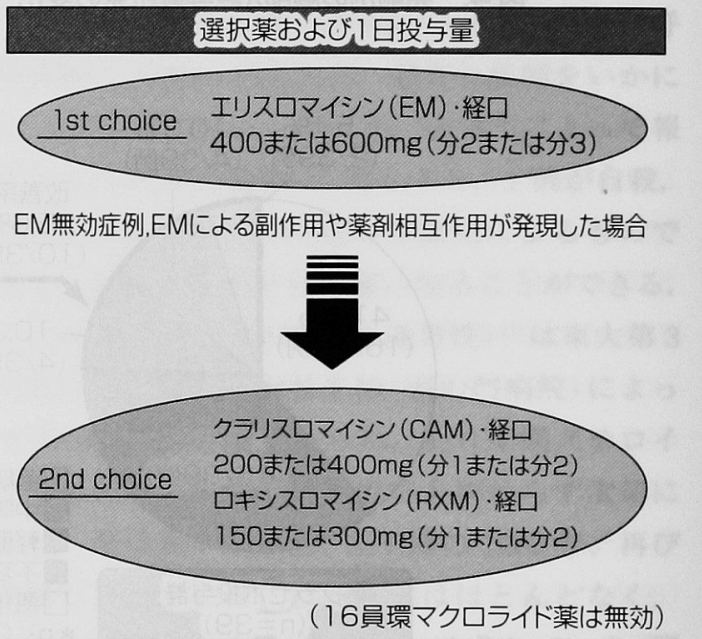

図 7. DPBに対するマクロライド療法の治療指針 その 1 (厚生省特定疾患呼吸器系疾患調查研究班「び まん性肺疾患分科会」最終案より一部改変)

程で，合併する慢性副鼻腔炎に関して検討した 洲崎ら ${ }^{42)}$ は, EM療法が下気道病変であるDPB のみならず，上気道の慢性副鼻腔炎についても 改善をもたらしていることを初めて報告した. 今日, EM療法は慢性副鼻腔炎に対する重要な治 療法の一つとして位置を占めている.さらに, DPB以外の慢性気管支炎や気管支拡張症 ${ }^{43)}$, 一部 の気管支喘息 ${ }^{44.45)}$ 等に対する有効性が報告され, 


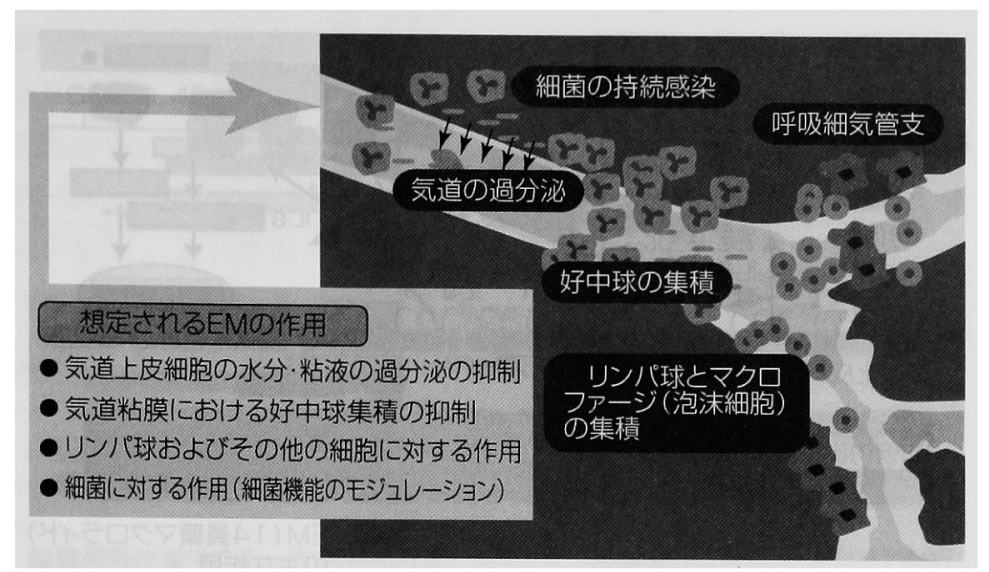

図 8. DPBの病態からみたEMの作用機序をめぐる主たる焦点

EM療法は上気道,下気道を問わず気道粘膜の慢 性炎症性疾患に対して, 広く用いられるように なった. 一方，薬版については，EMのみならず 同じ 14 員環マクロライドのcralythromycin (CAM), roxythromycin (RXM), さらに15 員環マクロライドのazithromycin $(A Z M)^{46)}$ など も有効性を示すことが知られ, EM療法は今日の マクロライド療法として発展することとなった. 図 7 は, 厚生労働省研究班によるDPBに対する マクロライド療法の治療ガイドライン47)であり, 第 1 選択としてはエリスロマイシンを, 薬㓮相 互作用などが愳念される場合にCAM，RXMを用 いるよう推奨している. AZMについては第三の 選択肢となろう。なおjosamycin（JM）などの 16 員環マクロライドは無効である.

\section{8. マクロライド療法の作用機序}

過去 10 年数間のDPBをめぐる研究の焦点は, EM療法ないしマクロライド療法の普及と同時に その作用機序をいかに考えるかにあった。 この 研究の推進にあたっては 1994 年, 呼吸器内科, 耳鼻咽喉科等の臨床領域と薬学, 細菌学, 免疫 学等の基礎領域の研究者によって設立された「マ クロライド新作用研究会」に負うところが大き (48.49).

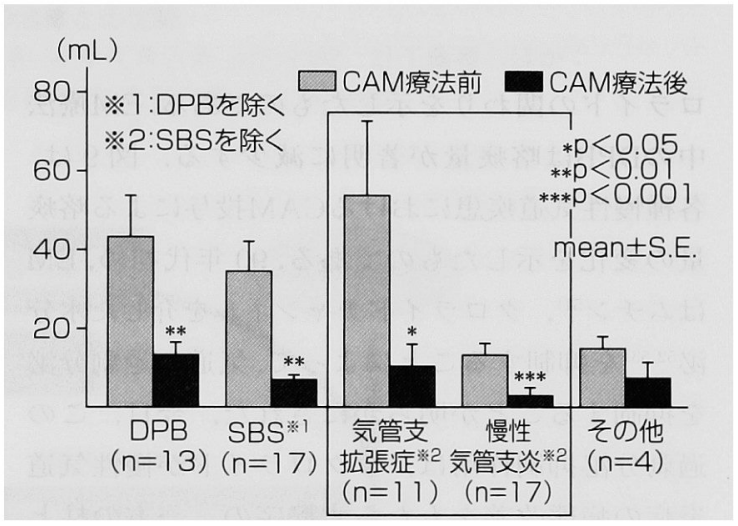

図 9. CAM療法前後の各疾患別の痰量变化 (谷本普 一ほか：第 20 回びまん性沉細気管支炎をめぐる研究 会誌 平成 6 年 7 月 東京)

DPBに対するマクロライドの作用機序が本来 の抗菌作用でないことは，前述のように菌を排 除しなくても疾患が改善すること, 感受性を持 たない緑膿菌感染症でも有効なこと，血中濃度 $\left(\mathrm{C}_{\mathrm{MAX}}\right)$ が $1 \mu \mathrm{g} / \mathrm{ml}$ 程度と MICレベルを下回って いること等の臨床的観察に基づいている.

マクロライド療法の作用機序をめぐる研究の 主たる焦点は，DPBにおける慢性気道炎症病態 との関連に置かれ, 主に炎症病態に関わる気道 上皮細胞, 好中球, リンパ球, マクロファージ などが標的細胞として検討されてきた.図 8 は, 現在まで明らかにされた気道の炎症病態とマク 


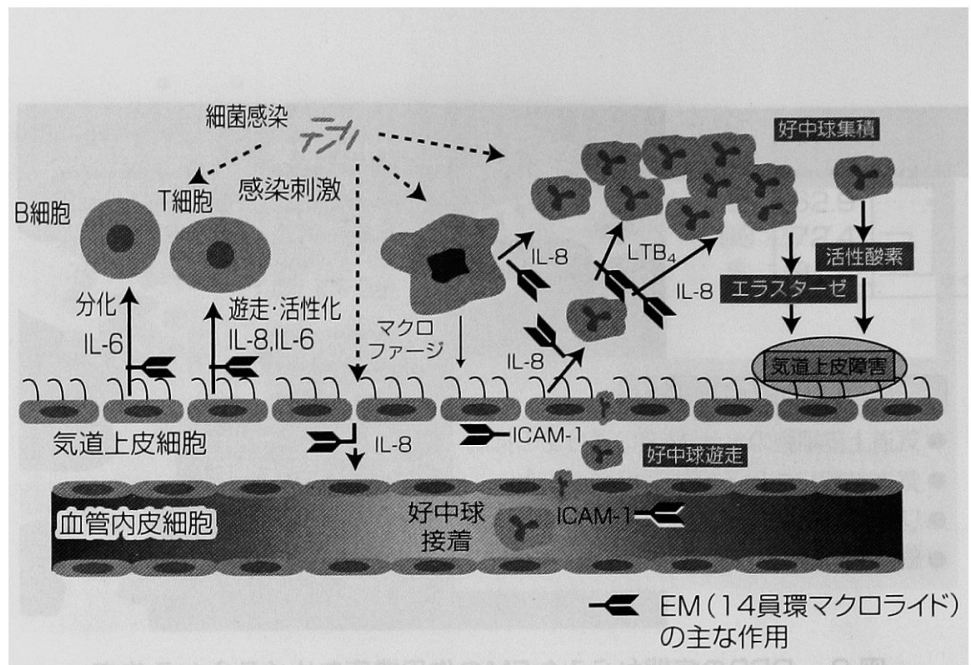

図 10. 好中球集積を中心とした慢性下気道感染症の炎症病㿟の概略

ロライドの関わりを示したものである.EM療法 中のDPBは喀痰量が著明に減少する. 図 9 は, 各種慢性気道疾患におけるCAM投与による喀痰 量の変化を示したものである. 90 年代初め, $\mathrm{EM}$ はムチン51)，クロライドチャンネルを介した水分 泌 ${ }^{52.53)}$ を抑制することによって,気道の過剩分泌 を抑制することが明らかにされた。 今日，この 過剩分泌抑制作用は, マクロライドが慢性気道 炎症の病態改善をもたらす機序の，一方の柱と して認識されている ${ }^{54)}$.

慢性気道炎症改善に関わるもう一つの柱は, 好中球炎症の抑制にある (図 10).マクロライド は, 好中球の血管内皮への接着の抑制, 上皮細 胞からのIL-8 遊離阻害, さらに, 好中球自身か らのIL-8 やLTB-4 などの遊離阻害などによって, 好中球の炎症局所への集積を抑制するととも

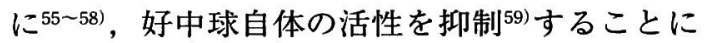
よって，好中球エラスターゼをはじめとする気 道上皮に対する傷害因子を隇少させる。このよ うな好中球炎症抑制作用は, 今日マクロライド の慢性気道炎症病態改善の中心的な機序として 理解されている.さらに, 気道上皮細胞におけ るIL-8mRNAの発現に関わる転写調節因子 NF $\kappa B$ 及びAP-1 の抑制作用が明らかになり ${ }^{60)}$, 副腎皮 質ステロイドとその機序においてどのように異
なるかが，新たな課題となりつつある.

\section{9. 慢性気道感染症における感染と炎症}

マクロライド療法の作用機序をめぐる研究の 中で, いま一つの重要なテーマは慢性気道感染 症における感染と炎症との関連であった. EM 療法以前の治療では, 感染病原菌をいかに抑制 するか最大の力点が置かれ, $\beta$-ラクタム薬をはじ めとする様々な抗生物質が, 主としてインフル エンザ菌を標的として投与された．にもかかわ らず，その効果は一時的であり，多くは緑膿菌 菌交代を生じ, 疾患の悪化がもたらされた。一 方, EM療法では感染菌の除菌がなくても疾患は 改善するが, 多数例でみるとインフルエンザ菌 のみならず, 緑膿菌も減少する傾向が窺われ, 正常細菌叢が増加する ${ }^{61)}$ (図 11)。これは気道感 染細菌叢の正常化誘導といってょい.

一方, MIC以下の濃度のマクロライドが, ど のように細菌機能に影響を及ぼすかも重要な研 究課題であった. 緑膿菌のバイオフィルム形成

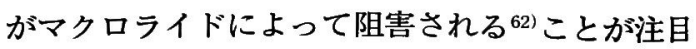
されてきたが，最近，バイオフィルム形成のみ ならず, エラスターゼ産生やピオシアニン色素 産生等の菌の毒性に関連するquorum sensing 


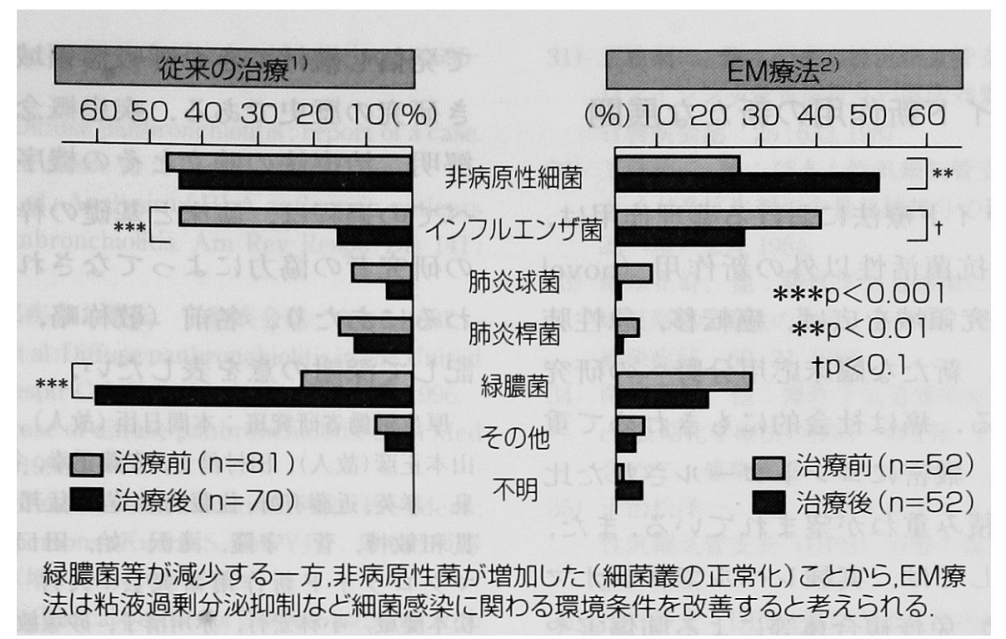

\section{图 11. 治療による咯痰細菌鋠の変化 \\ 一EM療法と従来の治療との比較一}

（1）木野稳也：厚生省間質性肺疾患調查研究班 昭和 56 年度報告書, p15, 1982 2 ) 工藤翔二ほか： 厚生省特定疾患「びまん性肺疾患」調査研究班 昭和 63 年度報告書, p.175, 1989)

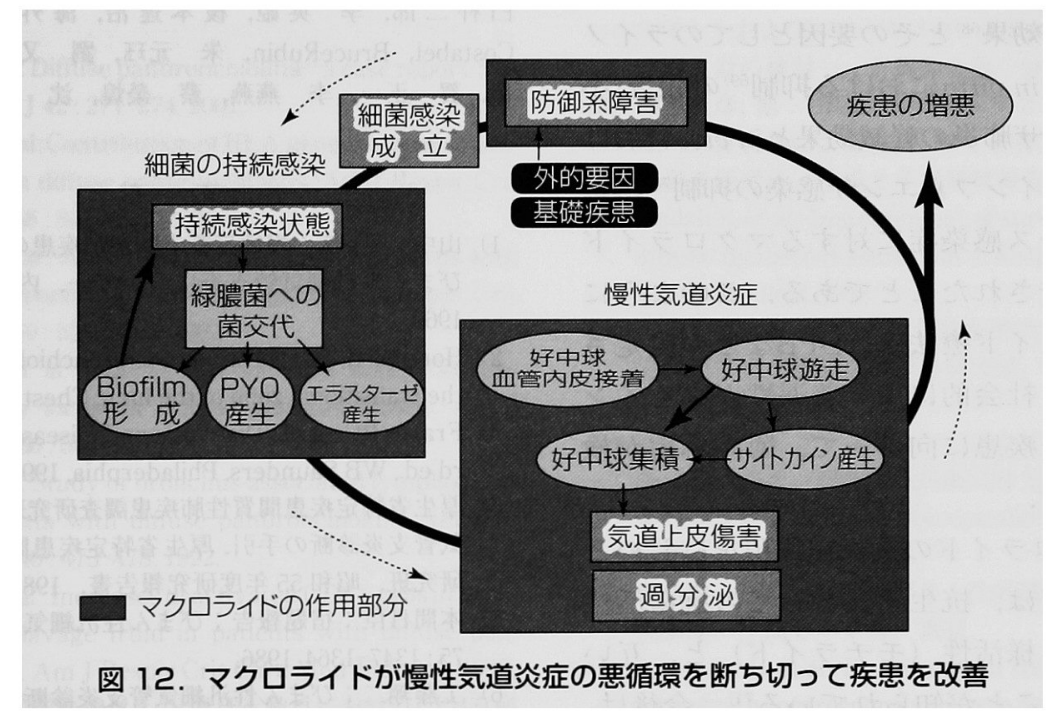

機構のマクロライドの抑制作用 ${ }^{63)}$ が明らかにされ た.

今日, 慢性気道感染症の視点からみたマクロ ライド療法は, 図 12 のように, 過剩分泌や好中 球炎症を抑制して炎症病態の改善をはかるとと もに，細菌の毒性を低下させることによって， 気道の感染と炎症の悪循環を断ち切り, 結果的 に感染そのものも良い方向に導いていると考え
られ，マクロライド療法は慢性気道感染症に対 する新たな理解と治療の展望を切り開くことと なった. DPBに対するマクロライド療法は, 前 述のように米国内科専門医更新試験に出題され るなど世界的にも認められ，そうした背景のも とに欧米においては, cystic fibrosisへの応用を 目的とした臨床治験が試みられつつある ${ }^{64 ~ 66) . ~}$ 


\section{0. マクロライド新作用の新たな展開}

現在,マクロライド療法における薬理作用は, マクロライドの抗菌活性以外の新作用（novel action）として研究領域を広げ，癌転移，急性肺 傷害の抑制など，新たな臨床応用分野への研究 が進められている．癌は社会的にもきわめて重 要な分野であり，峳密にコントロールされた比 較試験の今後の積み重ねが望まれている。また， 急性肺傷害に関しては，害験レベルでブレオマ イシン ${ }^{67)}$ ，シリカ，免疫複合体等による肺傷害や 虚血性再潅流肺傷害に対する報告がなされてお り, その臨床応用が期待されるが, 臨床試験に は到達していない.

最近のトピックスは,臨床におけるCOPD急性 増悪の臨床軽減効果 ${ }^{68)}$ とその要因としてのライノ ウイルス感染のin vitroに扔ける抑制 ${ }^{69)}$ の報告, 小 児インフルエンザ肺炎の軽減効果とin vivoにおけ る実験的致死的インフルエンザ感染の抑制 ${ }^{70)}$ の報 告など, ウイルス感染症に対するマクロライド の有用性が報告されたことである。このように 今日のマクロライド療法は, DPBなどの限定さ れた疾患から，社会的により普遍性が高くイン パクトの大きな疾患に向かって, 臨床応用が検 討されつつある。

14 員環マクロライドの抗炎症作用をはじめと する新たな作用は，抗生物質としての抗菌活性 およびモチリン様活性（モチライド）と，互い に独立していることが知られている71).今後は, マクロライドの構造活性相関や細胞内のシグナ ル伝達機構の掘り下げとともに，新作用に焦点 を絞った新しい 14 員環系マクロライドの開発が 期待されている.

\section{おわりに}

DPBの 35 年, マクロライド療法の 20 年に及 ぶ研究は臨床に出発し，日本から世界に向かっ
て発信し続けてきた呼吸器領域における誇るべ き研究の歴史である．疾患概念の確立，病因の 解明, 治療法の確立とその機序の解明に至るす べての過程は, 臨床と基礎の枠を超えた数多く の研究者の協力によってなされてきた，稿を終 わるにあたり, 名前（敬称略, 所属は当時）を 記して哚謝の意を表したい。

厚生労值省研究班：本問日臣 (故人), 山中 晃 (故人), 山本正产 (故人), 田村昌士, 安藤正幸, 谷本普一, 斎木茂樹, 泉 孝英, 近藤有好, 佐藤篤彦, 岩田猛邦(故人), 中田紘一郎, 貫和敏博，菅 守隆，滝沢 始，田口善夫，千田金吾， マクロライド新作用研究会: 大村智, 清水喜八郎, 松本慶蔵，小林宏行，赤川清子，砂塚敏明，洲崎春海，松島 網治, 沢木政好（故人），三笠桂一, 間島雄一, 大石和德, 玉賉 淳, 門田淳一, 山谷睦夫, 舘田一博, 中野由美, 東大 (旧) 第 3 内科第 5 研究室: 三上理一郎, 北村 諭, 杉山幸比古, 慶長直人，萩原弘一，都立駒达病院：木村 仁, 植竹健司 (故人), 後藤 元, 日本医科大学第 4 内科: 吾妻安良太, 曰杵二郎, 李 英姫, 榎本達治, 海外協力者: Ulrich Costabel, BruceRubin, 朱 元珏, 劉 又㲰, 胡 紅, 康 揵, 賀 正一, 李 燕燕, 蔡 笑煌, 沈 泳秀, 朴 明姫

\section{文献}

1）山中 晃,他：慢性気管支閉塞性疾患の問題点一とくに びまん性沉練気管支炎について一。内科 $23: 442-451$ ， 1969.

2) Homma H, et al : Diffuse Panbronchiolitis : A disease of the transitional zone of the lung. Chest $83: 63-69,1983$.

3) Fraser RG, et al: Diagnosis and Diseases of the Chest. 3 rd ed., WB Saunders, Philaderphia, 1990, 2224.

4）厚生省特定疾患間質性肺疾患調查研究班：びまん性沉細 気管支炎診断の手引，厚生省特定疾患間質性肺疾患調查 研究班，昭和 55 年度研究報告書, 1981, 13.

5）本間日臣：宿題報告；びまん性沉細気管支炎. 日内会誌 $75: 1347-1364,1986$.

6）工藤翔二：びまん性沉細気管支炎診断の手引き. 厚生省 特定疾患びまん性肺疾患調查研究班, 平成 6 年度研究報 告書, 1995,12 .

7）中田絋一郎：DPBの診断指針改訂と重症度分類策定。厚 生省特定疾患呼吸器系疾患調查研究班びまん性肺疾思分 科会, 平成 10 年度報告書, $1999,109$.

8）三上理一郎：気道感染症に捛ける上気道と下気道の相関一 いわゆる副鼻腔・気管支症候群における共通障害因子人 のアプローチ. 日気食会報 $26: 74,1975$.

9）潼沢敬夫：細気管支炎. 日本医事新報 $2626: 3,1974$.

10）工藤翔二, 他：副鼻腔気管支症侯群にお打了細気管支病 変の臨床的意義とその成因. 日本臨床 $36: 2484,1978$.

11) Kim $Y W$, et al : The first report of diffuse panbronchioli- 
tis in Korea : five case reports. Internal Medicine 31 :695701, 1992.

12) Chu YC, et al : Diffuse panbronchiolitis : report of a case. J Formosan Med Assoc 91 : 912-915, 1992

13) Sugiyama $Y$, et al: Analysis of HLA antigen in patients with diffuse panbronchiolitis. Am Rev Respir Dis 141 : $1459,1990$.

14）笹月健彦：胸部疾患と遺伝。日胸疾会誌 $25: 3.1987$.

15) Fitzgerald JE, et al:Diffuse panbronchiolitis in the United States. Am J Respir Crit Care Med 154 : 497-503, 1996.

16) Hu $\mathrm{H}$, et al : A case of diffuse panbronchiolitis. Chin Med J 109 : 949-952, 1996.

17) Symposium "Diffuse Panbronchiolitis in Asia(President: Ando M, Chairpersons : Kudoh S, Zhu YJ)". 日本呼吸器 学会雑誌 36 (增) : 103-108, 1998.

18) Tsang $K W$, et al:Clinical profiles of Chinese patients with diffuse panbronchiolitis. Thorax $53: 274-280,1998$.

19) Zainudin BM, et al: A report of the first case report of diffuse panbronchiolitis in Malaysia Med J Malaysia $1: 136$ 140, 1996.

20) Chantarotorn $S$, et al : Diffuse panbronchiolitis, the first case report in Thailand. J Med Associ Thai 82 : 833-838, 1999.

21) Poh SC, et al : Diffuse panbronchiolitis - a case report Singapore Med J 42 : 271-274, 2001.

22) Keicho N, et al:Contribution of HLA genes to genetic predisposition in diffuse panbronchiolitis. Am J Respir Crit Care Med 158 : 846-850, 1998.

23) Park MH, et al : Association of HLA class I antigens with diffuse panbronchiolitis in Koreans. Am J Respir Crit Care Med 159:526-529, 1999.

24) Keicho N, et al: Fine localization of a major diseasesusceptibility locus for diffuse panbronchiolitis. Am J Hum Genet 66 : 501-507, 2000.

25) Sato A, et al : Study of bronchus-associated lymphoid tissue in patients with diffuse panbronchiolitis. Am Rev Respir Dis $146: 473-478,1992$.

26) Mukae $\mathrm{H}$, et al : Increases of activated $\mathrm{CD} 8^{+}$cells in bronchoalveolar lavage fruid in patients with diffuse panbronchiolitis. Am J Respir Crit Care Med 152:613, 1995.

27）山口哲生：旧国鉄職貝とJR東日本職買におけるDPB有病 率の変遷. 厚生省特定疾患びまん性肺疾患調査研究班, 平成 6 年度研究報告書, $1996,157-160$.

28）中田紘一郎, 稲富恵子：病理組織学的にびまん性汎細気 管支炎々診断された症例に関する検討, 予後・治療。厚 生省特定疾患間質性肺疾患調査研究班, 昭和 56 年度研究 報告萻, 1982.25-28.

29）木野稳也：病理組織学的にびまん性沉細気管支炎と診断 された症例に関する検討；病体生理. 厚生省特定疾患 「間質性肺疾患調査研究班」昭和 56 年度研究報告書, 1982 , 22.

30）谷本普一,他：びまん性沉細気管支炎・自験例 15 剖検例 の検討.内科 $41: 906,1978$.
31）工藤翔二, 他：びまん性沉細気管支炎にたいするエリス ロマイシン少量長期投与の㫏床効果 -4 年間の治療成䅡. 日胸疾会誌 $25: 632,1987$.

32）工藤翔二, 他：びまん性㲸細気管支炎にたいするマクロ ライド系抗生剂の少量長期投与の踾床効果. 日胸疾会誌 22 (増) : 254, 1984.

33）澤木正好，他：慢性下気道感染におけるErythromycin の長期化学療法の検討一第一報：Amoxicillinとの対比一. 感染症誌 $60: 31,1986$.

34）澤木正好，他：慢性下気道感染症におけるErythromycin長期化学療法の検討一第 2 報 : Pseudomonas感染例も 含めて。感染症誌 $60: 45,1986$.

35）千治松洋一, 他：エリスロマイシン (EM)によるびまん 性沉細気管支炎 (DPB) 治療の䠦床的検討。日胸 45 : 299. 1986 .

36）田村静夫：DPB（慢性びまん性沉紐気管支炎）に対する 柴朴湯を含む併用療法の経験. 漢方医学 $11: 32,1987$.

37）工藤翔二,他：びまん性沉細気管支炎に対するエリスロ マイシン療法の臨床効果一関東地区多施設検討. 厚生省 特定疾患びまん性肺疾患調查研究班, 昭和 63 年度研究報 告書, $1989,175$.

38）山本正彦, 他：びまん性沉細気管支炎に対するエリスロ マイシン执よびニューキノロン采薬剤の長期投与の検討一 全国集計の検討一、日胸族会誌 $28: 1305,1990$.

39）山本正彦,他：DPBに対するエリスロマイシンの治療効 果一二重盲検による検討. 厚生省特定疾患びまん性肺疾 患調查研究班, 平成 2 年度研究報告書, 1991, 18 .

40) Kudoh S, et al : Improvement of survival inpatients with diffuse panbronchiolitis. Am J Respir Critic Care Med 157:1829-1832, 1998.

41）山本正彦，他：びまん性汎綝気管支炎の予後，厚生省特 定疾患びまん性肺疾㭧調查研究班, 平成 4 年度研究報告 書, $1993,235-236$.

42）洲崎春海：エリスロマイシンはなぜびまん性沉細気管支 炎に効くのか一びまん性汎細気管支炎に併発する慢性副 番腔炎に対する效果. Therapeutic Research $11: 29-31$, 1990.

43）谷本普一, 他：第 20 回びまん性汎細気管支炎をめぐる研 究会誌, 平成 6 年 7 月, 東京.

44) Miyatake $\mathrm{H}$, et al: Erythromycin reduces the severity of bronchial hyperresponsiveness in asthma. Chest 99:670673, 1991.

45) Konno S, et al : Antiasthmatic activity of a macrolide antibiotic, roxithromycin : analysis of possible mechanisms in vitro and in vivo. Int Arch Allergy Immunol 105 : 308316, 1994.

46）武田博明，他：びまん性沉細気管支炎に対するTE-031 長期投与の検討. 感染症学会誌 $63: 71-78.1989$.

47）中田紘一郎：びまん性沉細気管支炎治療ガイドライン最 釉報告. 平成 10 年度厚生科学研究特定疾患対策事業びま 乙性肺疾患調查研究班報告書, 1999, 109-111.

48）工藤翔二：マクロライド新作用研究この10年一臨床の立 場から. Jpn J Anibiotic 57 (Suppl) : 32-37, 2004. 
49）赤川清子：マクロライド新作用研究この 10 年一宿主側か ら. Jpn J Anibiotic 57 (Suppl) : 38-46, 2004.

50) Nagai $H$, et al : Long-term low-dose administration of erythromycin to patients with diffuse panbronchiolitis. Respiration 58 : 145, 1991.

51) Goswami SK, et al:Erythromycin inhibits respiratory glycoconjugate secretion from human airways in vitro. Am Rev Respir Dis 141 : 72-78, 1990.

52) Tamaoki J, et al : Erythromycin inhibits $\mathrm{Cl}^{-}$secretion across canine tracheal epitherial cells. Eur Respir J 5 : 234-238, 1992.

53) Ikeda $\mathrm{K}$, et al : Inhibition of acetylcholine-evoked $\mathrm{Cl}^{-}$currents by 14-membered macrolide antibiotics in isolated acinar cells of the guinea pig nasal gland. Am J Respir Cell Mol Biol 13 : 449-454, 1995.

54) Rubin BK, Tamaoki J : Macrolide antibiotics as biological response modifiers. Curr Opin Investig Drugs 1 : 169-172, 2000.

55) Ichikawa $Y$, et al:Erythromycin reduces neutrophils and neutrophil-derived elastlytic-like activity in the lower respiratory tract of bronchiolitis patients. Am Rev Respir Dis 146: 196-203, 1992.

56) Kadota J, et al: A mechanism of erythromycin treatment in patients with diffuse panbronchiolitis. Am Rev Respir Dis 147 : 153-159، 1993.

57) Ooishi K, et al: Role of interleukon-8 (IL-8) and an inhibitory effect of erythromycin on IL-8 release in the airways of patients with chronic airway diseases. Infect Immunity $62: 4145-4152,1994$

58) Takizawa H. et al : Erythromycin Modulates IL-8 Expression in Human Bronchial Epithelial Cells : Studies with Normal and Inflamated Airway Epithelium. Am J Respir Crit Care Med 156:266-271, 1997.

59) Umeki $S$, et al : Anti-inflammatory action of erythromycin. Its inhibitory effect on neutrophil NADPH oxidase activity. Chest $104: 1191-1193,1993$.

60) Desaki M, et al:Erythromycin suppresses nuclear factor-
kappaB and activator protein-1 activation in human bronchial epithelial cells. Biochemical \& Biophysical Research Communications $267: 124-820,2000$.

61）工藤翔二, 他：厚生省特定疾患びまん性肺疾患調查研究 班，昭和 63 年度報告書，1989, 175 .

62）小林宏行：宿題報告“びまん性沉細気管支炎に対するマ クロライドの作用機序”. 日本化学療法学会雑誌 43 ： 96-101, 1995.

63) Tateda $\mathrm{K}$, et al : Azithromycin inhibits quorum sensing in Pseudomonas aeruginosa. Antimicrob Agents Chemother 45 : 1930-1933, 2001.

64) Jaffe A, et al : Long-term azithromycin may improve lung function in children with cystic fibrosis. Lancet 351 (9100) : 420, 1998

65) Equi $A$, et al: Long term azithromycin in children with cystic fibrosis : a randomised, placebo-controlled crossover trial. Lancet 360 (9338) : 978-984, 2002.

66) Saiman L, et al: Azithromicyn in patient with cystic fibrosis chronically infect with pseudmonas aeruginosa: a randomized controlled trial. JAMA $290: 1749-1756,2003$.

67) $\mathrm{Li} Y$, et al : Fourteen-membered ring macrolides inhibit vascular cell adhesion molecule 1 messenger RNA induction and leukocyte migration : role in preventing lung injury and fibrosis in bleomycin-challenged mice. Chest $122: 2137-2145,2002$.

68) Suzuki $T$, et al: Erythromycin significantly reduced frequency of common colds and exacerbations in COPD. Chest 120:730-733, 2001.

69) Suzuki $T$, et al : Erythromycin inhibits rhinovirus infection in cultured human tracheal epithelial cells by reducing ICAM-1. Am J Respir Crit Care Med 165 : 1113-1118, 2002.

70) Sato $K$, et al: Therapeutic effect of erythromycin on influenza virus-induced lung injury in mice. Am J Respir Crit Care Med 157 : 853-857, 1998. 